\title{
Muḥammad Khudayyir from Saddam Hussein to the Gardens of the South: Writing the Self in Postcolonial Basra.
}

Fabio Caiani and Catherine Cobham

Department of Arabic and Persian, University of St Andrews, St Andrews, UK

https://www.facebook.com/fabio.caiani.18

https://orcid.org/0000-0001-7500-4602

Catherine Cobham (cmc1@st-andrews.ac.uk) on LinkedIn

orcid.org/0000-0002-6369-6629

Fabio Caiani

Department of Arabic and Persian,

School of Modern Languages,

Buchanan Building,

Union St,

St Andrews,

Fife

KY16 9PH

UK

fc8@st-andrews.ac.uk

word count: 9524 (incl. abstract, bibliography \& appendix); 11631 (incl. endnotes) 


\section{Muhammad Khudayyir from Saddam Hussein to the Gardens of the South: Writing the Self in Postcolonial Basra.}

In 2001 Saddam Hussein called on Iraqi writers to write novels inspired by the First Gulf War. Muhammad Khuḍayyir (b. 1942) responded to the presidential invitation by writing Kurrāsat Kānūn, a text that is neither a conventional novel, nor a celebration of Saddam's war. Khuḍayyir calls this new type of text an "assembling text," that is, a mixture of fiction, essay and reflections on war, and on artists from various times and places (e.g. Goya).

Kurrāsat Kānūn and the author's next "assembling text" represent an innovative mode of writing which is an alternative to both mainstream conventional fiction and the recent experimentations of Arab writers.

A reading of both texts that places Khudayyir within the contexts of various literary fields shows how his works express a vision of world literature from the perspective of a contemporary Arab writer who escapes both the threatening reality of post-independence regimes and the Eurocentric tendencies of postcolonial theory.

Keywords: Muhammad Khuḍayyir, Goya, hybridity, Iraqi fiction, postcolonial identity

I look out at the words that have become extinct in Lisān al- 'Arab I look out at the Persians, Byzantines and Sumerians And the new refugees I look out at the necklace of one of Tagore's poor women Crushed by the carriages of the handsome prince

I look out at my ghost

Approaching From 
Afar...

Mạ̣mūd Darwīsh, "Uțillu 'alā shabaḥ̄ qādiman min ba '̄id...," Limādhā tarakta al-ḥiṣān waḥidan?, 1995

\section{Introduction}

At the beginning of 2000, Saddam Hussein summoned some Iraqi writers and urged them to write novels inspired by the so-called Umm al-ma 'ârik, "The Mother of [all] Battles,"1 that is, the 1990-1991 Iraqi invasion of Kuwait and the US-led counter attack, commonly referred to in English as the First Gulf War. Muhammad Khuḍayyir (born in Basra in 1942) was among the writers whom the president met. A writer famous for his short fiction, Khuḍayyir responded to the presidential "invitation" by writing Kurrāsat Känūn ("The Winter Sketchbook", 2001), a text that, far from being a conventional novel (and far from celebrating Saddam's war), represents a key stage in the writer's literary development. ${ }^{2}$

With Kurrāsat, Khuḍayyir is confronted by a double challenge, posed by the real threat of Saddam's regime and the perceived tyranny of the novel. Khudayyir met this challenge boldly and in a way that allowed him to propose a distinctively innovative way of writing within contemporary Arabic prose literature: since Kurrāsat, he has mostly produced hybrid texts, which combine a sort of free form essay writing (that includes his musings on art, literature and war), autobiography and fiction. ${ }^{3}$ He has defined this hybrid type of text as naș jāmi", a "comprehensive/assembling text" which still includes short pieces that are the fictional expressions of the writer's visions and dreams. ${ }^{4}$ These "assembling texts" have two main functions. On one hand, they connect Khuḍayyir to the prose compilers of classical Arabic literature (and in doing so, they 
resist neo-colonial power dynamics); on the other, they are his way of responding to, and bypassing, the pressures of an authoritarian regime.

In this article, we propose to look at Khuḍayyir's work within the context of the recent development of Arabic fiction, but also in order to engage with questions raised by postcolonial theories in relation to this fiction (for example by Wail Hassan). ${ }^{5} \mathrm{We}$ will also base our discussion on close textual readings of some of Khuḍayir's texts, mindful of Mohamed-Salah Omri's question: "How is one to articulate the difference of Arabic literature if one does not tackle the makeup of the literary texts - their linguistic, generic, and narrative features - in addition to their 'contexts'?"6

The late Egyptian writer Idwār al-Kharrāṭ’s concept of al-hassāsiyya al-jadīda ("The New Sensibility") has been confirmed by many critics of Arabic fiction and Arab writers alike as a valid depiction of the innovative trends in the post-Naksa period. ${ }^{7}$ Arabic fiction is seen as developing beyond mimetic realism (at the service of any given philosophical order or ideology) along five main trends: alienation/estrangement, subjective introspection, use of turäth (both folk/popular and classical), magic realism, new experimental realism. ${ }^{8}$ While Khudayyir's writing clearly embraces some of these elements, the hybridity of literary genres that is the main feature of his works definitively contributes an innovative element to Arabic literature. ${ }^{9}$

Khudayyir's decision to move his writing even further away from a straightforward mimetic form of fiction by developing this innovative hybrid mode of writing allowed him to achieve various goals, both pragmatic and artistic. First, in Kurrāsat he finds the freedom to write about war and its disasters in a general and universal way (through his references to Picasso, Goya and Henry Moore), which is likely to have been far from the celebratory intentions of the regime, although this does not mean that he completely ignores the effects of Western military actions on Iraqi 
citizens. Secondly, the politically indirect and artistically sophisticated nature of his writing allows Khuḍayyir to reflect on his own status as an artist living under the rule of an authoritarian regime. ${ }^{10}$

Finally, this shift in Khuḍayyir's writing has been motivated by literary factors. Khuḍayyir has mentioned his favored hybrid form as a way in which to resist "the lure of the novel" (ighrā' al-riwāya). He decries the fact that writers in the Arab world continue to be too concerned with writing conventional novels and unwilling to experiment, and calls on Iraqi writers to be freer and braver: "How do we retain the power of the text to astonish [dahshat al-nașs], in the face of conformity and monotony?"11

Kurrāsat is based on a structure that Khuḍayyir goes on to replicate in a tighter, clearer fashion in his later Hadā 'iq al-wujūh: aqni 'a wa-hikāyāt ("The Gardens of the Faces: Masks and Tales”, 2008). In this text, Khuḍayyir (arguably freer, post 2003, to leave behind any direct discourse on war) reflects on some episodes of his life and the modern history of Iraq, writing a literary autobiography, accompanied by short pieces of fiction in which he pays homage to some of his muses. Far from being just a literary game, these sketches allow Khuḍayyir to voice the personal doubts and self-questioning of the individual artist. His writing is also intimately related to his daring theories of literature and art, and his articulation of a postcolonial cultural identity that celebrates the idea of a centerless world literature (and the contribution of the Arab literary heritage to this). In The World Republic of Letters, Pascale Casanova shows how world literature has its Western centers (dominated by French, English and German as languages representing literary empires and dominant cultures) and its (Western and) non-Western peripheries. Khudayyir ignores the center-periphery logic and is inspired by South-South cultural relations (the "'horizontal' links" of "the South-South 
paradigm" which Wail Hassan sees as a seriously understudied topic in Western postcolonial discourse). ${ }^{12}$

\section{Saddam's Iraq: Goya and the Rat.}

I dream your dreams, Goya [...]

Khuḍayyir, Kurrāsat Kānūn, 68-9.

Kurrāsat is an eclectic mixture of, on the one hand, reflections on the Gulf War of 1991, and the works of Goya, Picasso and Henry Moore, and on the other hand, fictional sketches inspired by Khuḍayyir's experience of the war, filtered through his knowledge of these artists' works. ${ }^{13}$

The writer's choice of Goya, Picasso and Moore as his subjects is significant in more ways than one, but primarily because of the works they created in response to war and violence. The book opens with a chapter that functions as an introduction of sorts, containing reflections on, and impressionistic references to, the content of the rest of the book. ${ }^{14}$ The well-known title of Goya's famous etching n. 43 of the Caprichos series (published in 1799) is here used as the opening epigraph: El sueño de la razón produce monstruos ("The Sleep/Dream of Reason Produces Monsters"), translated into Arabic as 'Indamā yanām al- 'aql tastayqiz al-wuḥush [When reason/the mind sleeps, monsters awake]. ${ }^{15}$

[Figure 1 near here] 
Khuḍayyir plays with the different ways of translating the original Spanish sentence and often chooses a more literal translation of sueño as ḥulm, [dream] (as opposed to nawm, [sleep]). A case in point is the first paragraph of the book that contains a poetic evocation of the circumstances surrounding the birth of the text:

I began in January 1991 to sketch a number of the faces crouched around the winter stove, clearly visible in the light from my old paraffin lamp and terrified by "the dream of the mind" that the Spanish painter Goya saw in the Madrid night, full of ghosts and uneasy premonitions, two centuries ago. The winter sketchbook contains sketches drawn in the nights of blackout that followed the air raids, and the time has come for the dreams in the sketchbook to express clearly the truths in my texts, which are now more than ten years old. (13)

From the beginning of the text, Khudayyir establishes a relationship of empathy with artists across time and space. Figurative art, which has always been a source of inspiration for him, is now explicitly acknowledged as such. ${ }^{16}$ His ambition in Kurrāsat is to create a "cubist" text inspired by Picasso's cubism, which he sees as a rejection of the "illusion of the three-dimensional" created by realist painting, and as such connected with "the actual moment of visual remembrance" (23), and he claims that writing can potentially achieve similar effects: it "can realize a cubist text by condensing past events in the present moment of imagination, that moment of recollection that includes details and particulars $[\ldots]$ the description of absent faces, the voice of muffled conversations, the stories of ephemeral incidents", which a fictional narrative (al-sard al-hik $\left.{ }^{2} \vec{\imath}\right)$ can retrieve from the world of dreams (ibid.). Like Picasso in his paintings, Khudayyir uses narrative in order first to depict an image and then to set it in motion. As John Berger 
writes: "The Cubists created [...] the possibility in art of revealing processes instead of static states of being."17

Picasso's art provides the overall structure of Kurrāsat and partly inspires its style, but it is the relationship that Khudayyir establishes with Goya that inspires the most memorable fiction in the text, and we will focus here specifically on his interaction with Goya. ${ }^{18}$

Khudayyir writes that al-hikāya, "the tale," can encompass more than one life, or one era. It is through this medium that Khuḍayyir establishes a dialogue with Goya: "My tale can try to make an etching from Goya's legacy and print from metal or stone an unknown caprice [capricho] of his" (65). Since this narrative etching is left untitled by the author, we will refer to it as "Goya and the Rat."

Khudayyir imagines Goya falling into a rat hole one dark, cold night as he is carrying hot soup home from a tavern for his ailing wife. Unable to escape from this hole, he is visited by one of the night creatures that come to him in his "dreams" or "sleeps" of reason and are depicted in his works: in Khuḍayyir's re-imagining, a rat (there are actually no rats in Goya's Caprichos). He has a conversation with the rat that is full of allusions to the nature of his work as a court painter, allusions that can be read as ironic comments on the nature of art and its relationship with coercive power. The rat has thrived since the beginning of the Spanish Inquisition: he has abandoned damp, dark holes in the ground, such as the one where Goya is currently trapped, for the comfort of rooms where the regime's secret files are stored, and for courtrooms and hospital kitchens (66). In a scene that is notable also for its black humor, the rat says to the painter:

I was born in a prison cell. I used to pass information to my friend, the condemned man I shared the cell with, telling him the truth about the verdict 
recorded in the secret dossier. It was a harsh sentence he didn't deserve. All the same, I think the judges are good men because they entrust their files to the members of my tribe, and they're really delicious. (ibid.)

Goya reveals his profession to the rat, describing himself as "the king's painter" (67). In the brief biography of the painter earlier in the story, Goya is described as "the principal court painter, and the principal people's painter [rassām al-balät al-awwal warassām al-sha 'b al-awwal]" (64). In his efforts to persuade the rat to rescue him, Goya promises to immortalize him in a portrait that will make him famous like a leader or a judge and "closer to us humans" (67). The rat is uninterested in such fame and says to Goya: "I only want to appear in your dreams, away from the spotlight... I can rescue you, old man... Is there anything a rat can't do?"19 (ibid.). The rat leaves Goya, saying he might be back with members of his family in an hour to rescue him, but both of them know this is unlikely: "The little hairs of [the rat's] moustache twisted ironically and he gave him a sad farewell glance, without looking him directly in the eye." Goya is left to question his own identity further:

Is he an actor, a jester, a fighter, a wrestler, a painter, an engraver, someone who lets his imagination enter prison cells? What kind of an image of him was reflected in the rat's piercing eyes and the rat's brain, that was crowded with images of condemned men? Is his [Goya's] madness any different from theirs? (67-8)

The narrative etching is over and now Khudayyir addresses Goya directly: they are two souls lost in the night, besieged by nightmares and the creatures of the night that Goya depicts in his works: "My dream enters your dream, and both dreams attract the night's lurking monsters to our rat hole" (68). Khuḍayyir rescues Goya and takes him to visit 
Basra at night, where he tries to picture the defamiliarising effects of war on the city through Goya's eyes:

Your hands in their courtly gloves have distorted the paintings of stores, restaurants, cafés, cinemas, barbers' shops and ice-cream parlors, taken down the old names and replaced them with the distorted names that will throw me into puddles and drains and upturn rubbish bins, strewing their contents in my path. (70)

The narrative style of "Goya and the Rat" is simple, concise and clear and as such contrasts palpably with the surrounding narrative, which is variously more polemical or more obscure. However, the fact that the style is linear does not indicate that the meaning of the story is readily available. What does the rat stand for? Is he friend or foe to Goya? And what is his relationship to the Spanish Inquisition? The critic 'Abd alJabbār al-Halfī sees in the reference to the portraits of famous leaders and judges a reference to Saddam's ubiquitous portraits. ${ }^{20}$ Another critic, 'Alī 'Abd al-Amīr, sees the rat as an interrogator from the Spanish Inquisition and therefore, by extension, from the Iraqi regime (and Kurrāsat as a whole is a text full of clear allusions to "the darkness" created by the Iraqi regime). ${ }^{21}$ In Kurrāsat, despite the necessarily indirect language, we can find some daring passages that seem to question the conduct of the Iraqi regime: the tragedy of the First Gulf War is seen as a full stop that marks the end of "a sentence suspended since 2nd August 1990" (37). The date mentioned is the day the Iraqi forces invaded Kuwait and so the ensuing period of war and embargo seems to be put into a context of cause and effect. Khudayyir also refers to the impoverishment of the language used by Iraqis during the war as a tragedy even more serious than material destruction (35) and comments on the subjective presentation of events from the Iraqi 
side of the conflict: "We too have our way of presenting our cause, of freezing an image or of arranging images [in a certain way]" (39). ${ }^{22}$

"Goya and the Rat" is Khuḍayyir's narrative capricho and, like some of Goya's own caprichos, is open to different interpretations. The artist's attitude to the characters and events he represents is ambivalent. The rat could be seen as a messenger from a world that Goya despised, that of the Inquisition and its prisons. However, whereas in many of Goya's etchings such creatures are disturbing symbols of madness and irrationality, Khudayyir's Goya summons the night creatures so that they can rescue him, and so the rat may also be a (mocking) representative of a side of the artist that is ready to collude furtively with tyrannical power.

There are interesting parallels between the rat and the character of a soldier in the story "al-Hukamā̄ al-thalātha" ("The Three Wise Men”, 1986) ${ }^{23}$ in their reaction to the function of art in periods of war and political oppression. The soldier's reaction to the reading of a poem ranges from a degree of sarcasm directed at the whole enterprise of writing poetry in a war situation - and poetry/fiction that not many people are ever going to read in any situation - to an acknowledgement of the genuine possibility that poetry is a way of enhancing or even extending life. ${ }^{24}$ In Kurrāsat, when Goya offers to paint the rat's portrait, the rat replies "What's the use of a painting to a rat? Is it food, or a pile of paper [...] that I can burrow into?" (66). This reading of the rat as the artist's disturbing alter ego is confirmed by the fact that the artist's own image is reflected in the eyes of the creature, who sympathizes with the victims of unjust powerful men, but lives off the latter, and is happy to hide in the shadows. Goya, with whom Khudayyir establishes such strong imaginative and artistic links, is here depicted as an isolated, self-doubting artist, who is uneasy about his relationship with a coercive political power and questions his representations of that power. 
In his study of Goya, Tzvetan Todorov bases his interpretation of Los Caprichos on the ambivalent meaning of the Spanish word sueño ("sleep" or "dream"). We have seen above how in Kurrāsat Khuḍayyir relies on the same ambiguity. In short, Todorov distinguishes between the Goya of "the sleep of reason" and the Goya of "the dream of reason." The former is the enlightened artist whose imagination, technical skill and knowledge of his art help him translate his own experience of the ills of his society into images that directly stigmatize the monsters produced by irrationality, ignorance, superstition, hypocrisy and abuse of power. The latter is a modern artist who directs his gaze towards himself and uses his imagination and dreams in order to explore his own demons, or, in the words of Foucault, "the dark night [in which] man communicates with his deepest being, and all that is most solitary within him." ${ }^{25}$ In order to read Goya's “communication with his deepest being” John Ciofalo divides Los Caprichos into two groups. The first group represents the malaise of society criticized from the point of view of Goya as an ilustrado (an intellectual espousing the ideas of the Spanish Enlightenment - Ilustración) - these are the etchings which attack the "sleep of reason." The second group of etchings is seen as a deforming mirror of the first group - these are the etchings which question "the dividing line between imagination and reason, dream and reality, darkness and light," the dividing line that "the Enlightenment sought to fortify and defend" - these etchings are the expressions of the "dream of reason." 26

In Kurrāsat, Khuḍayyir gives various forms to the disasters produced by the sleep of reason: for example, the bombing and shelling of Iraq in 1991 and the ensuing blockade, as well as the internal repression and the violence of the regime. On the other hand, he uses his imagination and his own art to join Goya in his "dream of reason." The writer explores the depths of his own subconscious by creating narrative images that are enigmatic and disturbing: that of "Goya and the Rat" is only one example. In 
the introduction to Kurrāsat, Khuḍayyir comments approvingly on Goya's self-portrait at the beginning of Los Caprichos (plate 1): he describes his "angry mouth" and a gaze that is scornful and compassionate in equal measure: nazra muzdawija min al-sukhriyya $w a-' l-$ 'atf (16). In Ciofalo's view, Goya in this self-portrait is playing with the idea of depicting himself as an ilustrado who is not amused by the etchings of the second group. When Khuḍayyir sees compassion in Goya's self-portrait, he is identifying with him but at the same time he is intrigued by, and appropriates for himself, the artist's questioning of his function. In Kurrāsat, the deforming mirror that Goya places in front of his ilustrado self in Los Caprichos finds an echo in the painter's courtly gloves that distort the once familiar names of public places of Basra and so we read a series of "compound titles" that are at the same time funny and disturbing: "The Bomber Qut alQulub," "Qays and Monica," "Schwarzkopf's Platinum Armor," "A Sail beyond the Tigris," "The B52 Madonna," “The Duchess of Alba” (70-71). ${ }^{27}$

The focus of both Goya and Khudayyir switches from the visible in the contingent reality to what is visible only in their imaginations. They do not represent the unreal in order to escape a traumatic reality, but rather as a way of understanding this reality whether it is war or their own demons - in a more far-reaching way: "the imaginary is not the opposite of the real, it is the best way to reach the real." 28 Todorov connects an unsettling of the social order to an unsettling of the rules of artistic representation that may lead to individual innovation. ${ }^{29}$ Similarly, Khudayyir justifies the increasingly fantastical fiction of his third short story collection Ru'yā kharīf("An Autumn Vision", 1995; a collection of stories written in the 1980s and the first half of the 1990s) by making a reference to the particular "unsettling of the social order" in Iraq, a reference 
which is jocular and at the same time alludes more seriously to the country's perilous political state:

Reality never sides with unreality except when it is reined in, nailed down, oppressed by unpleasant surprises, stripped of its innocence, its simplicity, its impartiality, its social fabric, its regular chronology... So do not listen to its complaints! $!^{30}$

As we have seen above, this stepping away from a mimetic representation of the external reality was one of the features of a new mode of writing in the Arab world that Idwār al-Kharrāṭ called "The New Sensibility.” As a result of his 2000 meeting with Saddam, Khuḍayyir was put directly under the constraints of the regime and its request to deal with the external reality of war, a real-life "unpleasant surprise," an example of reality "reined in, nailed down." It is clear that for Khudayyir it was becoming increasingly important to assert the independence of art and literature from received history and political pressure. This concern will become more unequivocally articulated in his next nașs jāmi', Hadā'iq al-wujūh: aqni 'a wa-hikāyāt ("The Gardens of the Faces: Masks and Tales”, 2008), which is an innovative self-portrait in words, that will tell us much about the author's conception of literature and his fashioning of a highly eclectic literary identity that is relevant within postcolonial discourse. In writing his own history, real and imagined, Khuḍayyir creates a literary persona which allows him to explore Iraq from a personal and a postcolonial perspective.

\section{After 2003: Gardens of the Global South.}


"I thank you that I am not one of the wheels of power, but one of those crushed by the wheels of power."

Tagore, Stray Birds, n. 49, translated from Khuḍayyir's Arabic; Khuḍayyir, Mā yumsak,

5.

As we have seen above, Kurrāsat, is an example of what the author calls nașs jāmi', "an assembling text" that is meant to offer an alternative form to conventional novels and allow Khudayyir to deal with the demands of the Saddam regime in a creative way. ${ }^{31}$ Hadā 'iq is the author's next book-length hybrid text: both texts combine different literary genres, such as fiction, autobiography and essay writing. ${ }^{32}$ However, the two texts differ from one another in significant ways. First, in Kurrāsat, Khuḍayyir makes direct references to the First Gulf War and its aftermath. In Hadā 'iq, he includes no direct references to the events of the new millennium, such as the sectarian strife that was particularly violent between 2006 and 2008, the year in which the book was published. War here is confined either to the context of history or to that of folk-tales, and is always in the background. This suggests that the writer felt under pressure from Saddam's regime to make references to the Gulf War and the embargo years in his earlier text. Both texts can be read as parts of a self-portrait by a contemporary Arab writer who ingeniously escapes the trappings of the threatening reality of postindependence Arab regimes and the Eurocentric tendencies of postcolonial theories. In this sense, Hada 'iq builds on the discourse that Khuḍayyir began in Kurrāsat regarding writing the self, drawing on Goya's ambiguous self-portrait, but developing new cultural alliances. A writer writing in the 2000s goes back to his early life when Iraq was controlled by Britain and, whereas he deals indirectly with the marginality of the 
colonized, his cultural frame of reference is now focused on the Arab-Islamic turāth, and on Latin America and India, i.e. formerly colonized regions. Muhsin Al-Musawi sees autobiography as "a counter-narrative" and "a reconstituted selfhood [...], giving the lie to Orientalist representations and colonial applications." ${ }^{, 33}$ Although Al-Musawi is in this case referring to conventional autobiographies by Arab writers, his observations can also be applied to Khuḍayyir's hybrid and assembling form of "selfwriting”. Khudayyir writes too to show how he and his city fit into this history, and to engage with what Stuart Hall, writing about his Caribbean identity, calls the "constantly shifting process of positioning" the city and himself within the legacy of colonialism. ${ }^{34}$

Before we develop the postcolonial implications of the text in more detail, we will first describe its general structure and conceptualization. The text is made up of clearly distinct sections: an introductory chapter followed by seven further sections. The introductory chapter, entitled "The Gardener" (“al-Bustānî̀) gives the whole work a captivating and ambitious allegorical dimension. The book is a literary autobiography, based on the allegorical depiction of the writer as a gardener. ${ }^{35}$ After the introductory chapter, the first section, entitled "The Garden of the Ages," is made up of a series of sketches clearly informed by people, events, images and stories emerging from the life of the first person narrator (Khuḍayyir himself, or at least an authorial persona who is given the name of "the Face"), from his birth to when he is sixty. ${ }^{36}$

Another telling feature of these sketches, and one which connects them to the stories included in Khuḍayyir's first collection, al-Mamlaka al-sawdā' ("The Black Kingdom", 1972), is the way in which contemporary momentous events like wars and revolutions remain in the background, and the focus is on seemingly unimportant people who live at the margins of twentieth century history: a midwife, a smuggler, a sailor from a faraway land, a nightwatchman and his dog, a country schoolteacher, etc. The 
stories of these seemingly unimportant people provide snapshots that have been excluded from the official history of the twentieth century. ${ }^{37}$ The vision that these sketches creates is episodic, personal and unreliable. For example, the two-page sketch "The Face as a Middle-Aged Man: A Guard from Zanzibar" begins with the narrator introducing his grandfather as "a guard of nothing" (33). The old man, despite having witnessed two of "the wars of the river" (i.e. the wars in Iraq) and one of its revolutions, merely narrates his love story with a woman from Ahwāz (Iran) and the story of a guard "from Zanzibar or Baluchistan," but at every new telling "facts get mixed up in his story, just as the current mixes up the gifts of the sea or the rubbish from the bars on the river bank" (34). The grandfather, who used to work as a guard on the boats of a British date exporter, is left jobless when the company leaves after "one of the river's revolutions" (33). He and a sailor "from Zanzibar" now keep guard over the rubbish which floats on the river. One day the exiled sailor-guard, who lives alone on an abandoned ship, fishes a soldier's helmet out of the river. He finds inside the lining of the helmet a letter that water has turned into a sort of mysterious talisman. The guard hangs the helmet on a hook in his cabin.

On nights when the big river moon was shining and its light fell on the helmet, the symbols of the letter that had never reached its destination would appear very clearly to the guard, the letter of the soldier to his family, or the letter of the guard to his family living in a faraway place in Zanzibar or Baluchistan. (34)

In only two pages we have the poetic intersection of different lives: the stories of the narrator's grandfather, the forgotten guard and the unknown soldier are all lost in history and in a small corner of the world, Southern Iraq, which is nevertheless often depicted in Khuḍayyir's works as a richly cosmopolitan center, especially in its pre- 
independence history. ${ }^{38}$ The narrator ends his story with a typically brief reference to people and places lost in time: “My grandfather died and I've never been able to place this soldier, who lost his helmet in one of the wars of the river, since I first heard this story in 1958 in my sixteenth spring" (ibid.). Despite the melancholy tone that often permeates these stories, some of the experiences of these people lost in time have been put down on paper and vividly preserved in lyrical and sensuous detail. ${ }^{39}$

This lyrical recording of the experiences of the marginalized is indicative of a specific postcolonial perspective. As we have mentioned above, Casanova shows in The World Republic of Letters how world literature has its Western centers and its (Western and) non-Western peripheries. From this global perspective, it is possible to see Khuḍayyir embracing the marginality of Southern Iraq in order to put the subaltern at the center of his remembrances of things colonial and postcolonial. Even from a strictly Arab perspective, Khuḍayyir can be said to represent one of the peripheries Casanova talks about: his work does not represent the traditional centers of Arab culture, Cairo and Beirut (and not even the new would-be cultural hubs of the Gulf). Even within the Iraqi context, Khuḍayyir is geographically at least not of the center: Basra, its rich cultural tradition notwithstanding, is not the capital Baghdad, the undisputed cultural center of the country.

In these ways, his work (both his fiction and his literary criticism) can be read as his own oblique way of "writing back" to the centers of old colonial empire and the centers of the new global empire of capital which have been keen to control Iraq (and the Arab world more generally) economically and politically, but have shown little interest in its rich culture and literary tradition.

Within this postcolonial perspective, the upstaging of the protagonists of history by the unknown people at its margins is nowhere clearer than in the chapter "The 
History of a Face: Maude the Conqueror" (47-9). In this sketch, the narrator describes in detail and with some irony a photograph that depicts General Maude entering Baghdad in 1917: "In front of us we have a photograph of the hero Maude entering [Baghdad] $[\ldots] "(47)$.

[Figure 2 near here]

After that, he ignores the "hero" Maude and lets bì bi (granny) Badūr speak, as she is the only witness of the event whom the narrator can find. She claims that she took from the invading British army as spoils of war a young soldier, "wearing shorts, with a waxed moustache erect on his drooping lips" (48). She had two daughters by him "who were carried away by the cholera that ravaged the bowels of their father, and also those of his master, Maude" (ibid.). The narrator is unsure whether to believe Granny Badūr's fantasies, as he has failed to find another witness of the General's entry into Baghdad, so we are destined to remember the story of an old woman who is "shared between the households," a woman who, having fled an old people's home, "was like the eternal mother to all those frightened people fleeing on the roads of history, the roads of faded photographs" (49).

These people might be said to lack agency but we are far from the voiceless other of orientalist (and postcolonial) discourses, not only because the subaltern occupies center stage in the narrative, but also because of the poetic empathy with which Khudayyir evokes their predicament. If the photograph of Maude entering Baghdad is part of the colonial archive ("a whole history of a country can be captured in a snapshot ${ }^{\prime 40}$ ), Khudayyir's poetry is placed against this archive. ${ }^{41}$ 
In his more recent collection of autobiographical texts, Khuḍayyir writes about growing up in a specific colonial context and identifies the time of his birth explicitly with the beginning of the British occupation of Basra in World War II. ${ }^{42}$ He recalls the British owners of the date exporting company which employed his father: "The red faces of the company owners suggested to me power, domination, control, satiation," and contrasts them with the Iraqi date packers with their "characteristically haggard faces" and "peaceful, good-natured features." He directly attributes the initial inspiration for his reading and writing to his pre-school trips with his father to the British company's date presses on the other side of the Shatt al- 'Arab and the villages hidden among the date palms: "I found the future of my reading and writing in everything the river said." 43

With Bībì Badūr and other "people of the river," Khuḍayyir draws our attention to those who have been forgotten by history and appear as mere extras in the photographs which document the exploits of empire. This fits into a specific mode of postcolonial writing from the margins that has the effect of subverting colonial discourse and orientalist attitudes. Khudayyir's writing explores what Fanon calls "the zone of occult instability where the people dwell," ${ }^{44}$ instead of subscribing to the more common attempts to go "back to a 'true' national past, which is often represented in the reified forms of realism and stereotypes." 45

Wail Hassan and many other critics have pointed out how this postcolonial perspective inevitably has the empire it confronts as its sole, or main, frame of reference. ${ }^{46}$ This is not the case in the second part of Hadā' iq. This section is striking for the absence of the colonial, or neocolonial/postcolonial, referent: Britain, Europe or the West as a whole are largely absent as sources of inspiration for Khuḍayyir's postcolonial "gardener," his 
literary persona ("the Face"). This is significant as this section is geared towards the creation of a literary persona and includes literary homages to some of Khudayyir's muses. In the introductory chapter of the book, Khudayyir mentions a succession of “gardeners:” Epicurus, Rūdakī, Kushājim, Rūmī, 'Umar Khayyām, Ḥāfiz, Sa 'dī and Badr Shākir al-Sayyāb. ${ }^{47}$ The predominance of classical Persian poets in this list shows an acknowledgement of a shared Arab-Persian Islamic cultural heritage that Khudayyir recognizes as his own. ${ }^{48}$ The six gardens (inspirational sites) he decides to include in the second part of the book are dedicated to cultural figures who belong to that heritage, but also to representatives of the modern cultures of non-European regions: India and Latin America: Tagore (the garden of silence - whose themes are loosely based on meditation and Hinduism); Gabriel Garcia Marquez (the garden of the century - where a post-Third World War future is imagined); Borges (the garden of the world - based on a universal and timeless conception of storytelling); Jibrān Khalīl Jibrān (the garden of the prophet - where painting and art are discussed); a series of classical Arab poets noted for their love poetry (the garden of love - where sensual and mystical forms of love are referred to); and al-Ma arrī (the garden of forgiveness - which hinges on a meditation on asceticism and death).

It is not incidental that Khudayyir's theoretical discourse on the universal nature of literature and the anonymous, fluid identity of writers find echoes in his treatment of Hindu spirituality in the first fictional piece of the second part of the book: "al-Būrān̄̄" which is the name Khuḍayyir gives himself here and in some of his other hybrid texts (for example, see the appendix below). This a reference to "the Purani," "the oral transmitter of the Mahabharata and Ramayana" (61), inspired by Tagore. At this point, Khuḍayyir's work goes beyond the North-South perspective, the center-periphery 
paradigm, on which, as Hassan has observed, much postcolonial theoretical discourse has been based. ${ }^{49}$

\section{Conclusions}

"Theories hang about and mount up on the tables of critics, while writers would like to clear these tables so that they could write free of any obstacle or external supervision." Muḥammad Khuḍayyir, "al-Qișṣa al-qașīra.”

\section{1) Khudayyir and the postcolonial literary field.}

Khuḍayyir's hybrid and eclectic writing is an expression of his unconstrained choice of subject matter, sources of inspiration and literary form. At the same time, this writing represents a quest for the independence of literature from history, politics and the expectations of rulers and readers alike. In the Preface to the English translation of her ambitious study La république mondiale des lettres, Casanova writes of "great writers" who "have managed, by gradually detaching themselves from historical and literary forces, to invent their literary freedom, which is to say the conditions of the autonomy of their work." ${ }^{50}$ Khuḍayyir's pursuit of independence can also be seen as the effort of a postcolonial Arab writer to escape from the postcolonial and neocolonial logic of the international field of literature that is dominated by the West. The readers of Casanova's book soon realize that the "great writers" she mentions are writers who do not write in Arabic, Chinese or Hindi, but in European languages (or at least they are writers whose value has been sanctioned in the Western literary centers). She writes about nonWestern languages as follows: “[...] there are languages of broad diffusion such as Arabic, Chinese and Hindi that have great internal literary traditions but nonetheless are 
little known and largely unrecognized in the international marketplace" (256-7). In this article we have discussed an unorthodox voice (or an "eccentric" voice, in Casanova's formulation, 353) from one of those non-Western "great internal literary traditions," as it is a voice worth hearing, not only for what it has to say about Arab culture and literature, but also because it articulates a vision of the world republic of letters from an Arab perspective. The power dynamics of literature in the world have been accurately described by Casanova. However, an exploration of Khuḍayyir's work calls into question her belief that every writer in the world aspires to be recognized and consecrated by the Western center (17). Khudayyir's intended readership is clearly meant to be Iraqi and Arab, as his main concern is to contribute to the development of Arabic literature in innovative ways that are open to inspiration from the Arab world's literary heritage (mainly Islamic, but also pre-Islamic) and to the fruitful connections between it and the literatures of the global South. ${ }^{51}$

Khuḍayyir's writing expresses vis-à-vis this international republic of letters a seemingly contradictory stance: on one hand, he is aware of the powerful gravitational forces that the Western center exercises on Arab culture and fiction, and his selfconfident freedom to be open to any source of inspiration at times inevitably takes him towards this center. As we have seen, Kurrāsat is a work based on a dialogue with European artists, and Khuḍayyir acknowledges this postcolonial mimicry, happily overstating his case: "I did the sketches in my notebook by copying their sketches [i.e. those of Goya, Picasso and Moore]. I copied my time by copying their visions."52 On the other hand, he calls fellow Arab writers to be innovative and open to inspiring creative forces that are alternatives to the Western centers (and this call is implicit in the ways in which he develops his frame of cultural references in $\operatorname{Had}_{a}$ 'iq). 
A few days after the inauguration of Donald Trump as the new American President on 20 January 2017, Khuḍayyir wrote an article entitled "Alāma 'A 'ida" (“A Recurring Sign"), which shows his awareness of the existence of "a dominant center" (the West) and "a dependent periphery" (here he refers to Arab writers). ${ }^{53}$ Khudayyir sees Trump's divisive election as a potentially pivotal moment in world literature that will galvanize and radicalize American novelists and marginalize African and Asian narratives. He expresses his dissatisfaction with the postcolonial novel in the Arab world, which he sees as conforming to, and imitating, Western narratives, and he connects the postcolonial phase with a colonialism that needs to be resisted. The fundamental question he asks in this article is: "Do Arabs have enough freedom and the courage required to stand up to the modernity of the Western center?"54 Bearing in mind that Khuḍayyir's critical writings are ultimately always indirectly about his own creative works, he is here clearly alluding to his own texts as constituting an alternative to this unsatisfactory dependency on Western literature and culture. Kurrāsat and Hada 'iq are the expressions of his theories of literature that forcefully depict the international republic of letters as "a centerless universe" ('ālam bilà markaz), ${ }^{55}$ in which the Arabic-Persian, Latin-American and Indian galaxies are juxtaposed, without any deference to the Western galaxy.

\section{2) Khudayyir and the Arab literary field.}

The two texts discussed above are extremely different, not only from Khuḍayyir's own early stories, but also from fiction written by other contemporary Iraqi writers. It is worth noting that the fragmented and hybrid nature of these texts is also present in works written by new Arab writers whom Tarik El-Ariss refers to as "hackers." However, whereas these writers react against the literary establishment by writing 
subversive blog-like texts, Khudayyir reacts to mainstream Arab fiction by producing texts that are sometimes deliberately esoteric and highly literary. His texts are at the other end of the literary spectrum from those produced by these younger writers. For example, Ḥasan Balāsim (an Iraqi writer living in Finland) writes in a more linear, demotic language, employing shock tactics to negate the distance between events and the reader ${ }^{57}$ and ambitiously moving the written language closer to the structures and freedoms of the spoken languages.

Clearly dissatisfied with what conventional novels offer, ${ }^{58}$ Khudayyir has explored science fiction and the Arab-Islamic turāth in search of inspiration (some passages in both Kurrāsat and Hadä iq, along with some of the stories included in $R u^{\prime} y \bar{a}$ kharîf, can be read as a highly sophisticated form of sci-fi). As early as 1995, he complained that science fiction was a literary genre largely untouched by Arab writers, whom he also accused of neglecting their own rich literary heritage. He mentions the Egyptian Jamāl al-Ghīṭānī and the Syrian Zakariyyā Tāmir as two exceptions, who have successfully used the turāth in their works. ${ }^{59}$ However, while Tāmir relies on a fluid and linear style, some passages in Khuḍayyir's Kurrāsat and Hadā 'iq are so obscure as to make us think that we can only fully understand and appreciate them if we manage to discover the sophisticated literary references around which they are constructed. On the other hand, this fiction, seemingly divorced from the contingent reality of Iraq, does carry a discourse on art and culture which, in its ecumenism and universalism, goes against the various sectarian narratives that have increasingly dominated Iraqi reality after the change of regime in 2003 (a year Khudayyir refers to in his journalistic articles on fiction as the year of change, al-taghyir $)$ and challenges the hierarchical logic of postcolonial (or neocolonial) cultural globalism. ${ }^{60}$ Hadā iq was published in 2008 after a period in which many Iraqi civilians were killed in sectarian clashes, while in recent 
years extremists have been endeavoring to impose their violently exclusivist conception of Islam in parts of Iraq and the Arab world. Within this context, it is significant that Khuḍayyir exploits the hybrid nature of his two "assembling texts" to make them as inclusive as possible, by including references to a wide range of cultures from preIslamic Iraq to Hinduism. Similarly telling is the fact that Hadā iq ends with a section in which the writer seems to suggest that human existence oscillates between a sensual dimension and an ideal ascetic one, the latter represented by Abū al- 'Alā' al-Ma 'arrī (973-1057). Al-Ma arrī’s skepticism, which the narrator is sympathetic to, may help us understand the symbolic end of the book as he implies that the ideal represented by a mystical, ascetic life is not always attainable and, more specifically, the craft of writing might be one with no practical end or clear meaning.

\section{3) “Meeting Saddam” Revisited: the Party's Over.}

According to 'Alī 'Abd al-Amīr, the Iraqi writers whom Saddam summoned at the beginning of 2000 and urged to write novels inspired by his latest war, remembered the "fragility" (rahāfa) of Khuḍayyir in the huge vaulted hall of the president's palace. Khuḍayyir's discourse to the effect that art and culture transcend temporal and spatial boundaries and are the shared heritage of all human beings might look irrelevant in a period dominated by corrupt or ineffectual politicians and extremists. Even so, his stories indirectly express the hope that the lofty palaces of Iraq's coercive regimes and the destruction visited on the country and its people will pass, whereas the inclusive vision promoted by Khuḍayyir and other "fragile" men and women will survive. Ironically, Saddam himself told Khuḍayyir and his fellow writers that political slogans are ephemeral, whereas culture and literature will remain. ${ }^{61}$ 
However, the author, whose ambivalence regarding his role as a writer has been discussed above, goes back to the meeting with Saddam in his latest naș jāmi', “assembling text," Aḥlām Bāṣūrāa ("Bāṣūrā’s Dreams”, 2016), in a sarcastic way that is humorous and disturbing at the same time. In the two-page "Nihāyat al-hafla" (literally "The End of the Party"; see Appendix for an English translation of the story), Khudayyir clearly refers to his meeting the president at the beginning of 2000 , even though Saddam is not named and writers are referred to by pseudonyms. Instead of reiterating the optimism that literature and art can survive the temporary tyranny of power, Khuḍayyir paints a surreal sketch in which the Iraqi novelists are seen as hypocritical opportunists in cahoots with power. Punished at the end by their own greed and eagerness to please the powerful they are turned into the flawed characters of one of the president's novels, to the president's delight.

Some critics might have wanted and expected Khuḍayyir to reflect on his own experience of meeting Saddam by writing a much more easily decipherable message with a direct stigmatization of the president and his regime and a celebration of heroic men of letters who opposed it. Instead, in this short piece, Khuḍayyir shows the extent to which the writers were made to play the game of power controlled by the president and submit to this debasing and corrupting game. This shows Khudayyir to be once again an original and unpredictably independent voice, not only within contemporary Iraqi literature, but also in Arabic literature more generally. This skeptical attitude towards power (be it local tyrannical power, or the power of foreign superpowers and their cultural discourses, or even that of the critics and their expectations), allied to a self-questioning tendency, is part of Khuḍayyir's postcolonial identity. 
Appendix. A translation of "Nihāyat al-ḥafla" by Muḥammad Khuḍayyir, Aḥlām

Bașūrā. Baghdad, Beirut and Freiberg: Manshūrāt al-jamal, 2016, 156-7.

\section{The Party's Over.}

The great hall of the palace was ready to welcome the novelists. The president himself distributed the prizes. $M$ received first prize, two medium-sized suitcases filled with cash, and at the end of the ceremony a fire destroyed all the prizes.

The novelists were invited at noon to the palace known as the Palace of the Lake and they sat facing each other behind two long tables set up around the lake, encircled by the palace guard. They waited a long time for the president to make his entrance and didn't utter a word during lunch. When the president did appear, they rose to their feet and turned towards him, applauding him with their sweaty palms. After a lengthy discussion about the characteristics of the realist novels, that the president composed in the course of his political and social work among various strata of the people, the prizes were distributed, the biggest going to $\mathrm{M}$, but the resentment that built up against him deep in the writers' souls was not unleashed until the president left the hall with his aides and his bodyguards.

The first to attack the winner of the palace's most prestigious prize were a dark-skinned writer who called himself the Baghdad Othello and a woman who had taken the pseudonym Fid'a 'Imāriyya, but the real maestro in the anarchy that set the great hall ablaze was a veteran novelist who looked like the hunchback of Notre Dame. And of course my pseudonym Būrānī, the story-teller, was well known to the writers in the hall. Into the crush of writers slipped a man who resembled an executioner or a doctor in a psychiatric hospital, and he took another name for himself as the presidential 
game demanded. The president had said in his talk that he didn't write his novels under his real name, a tradition from the days of the underground struggle.

Politeness and undue obsequiousness were apparent on the faces of the invited writers, and in their conversation in the presence of the president and his guards and ministers, but once they withdrew, the writers turned against their borrowed characters and improvised slanderous dialogue and crazy, disruptive action. Then the punishment ceremony ended with the prizes the president had distributed being set on fire.

The hall was emptied of the two long tables and its many windows were divested of their curtains, and the winner of the first prize was pelted with the statuettes and books and pens and phones that had been strewn over the floor, and computer disks flew through the air and smashed into the windows. Then the contents of the two suitcases were distributed far and wide and when the floor of the palace was awash with bundles of new banknotes, these were doused in petrol. This crazy impromptu uprising played out like a confusing chapter in one of the palace's novels, as the anger of its deranged characters erupted and they set parts of the palace on fire. The guards locked the two big doors of the hall and the writers jumped out of the windows, after smashing what remained of the glass. The fish in the lake leapt into the air as the fire blazed and its heat spread into the water.

The last face the prizewinner M saw was the president's, grinning from ear to ear, as through a spyhole in one of the doors he looked down upon the ceremony of destruction which was taking place according to his wishes, with the collusion of the writers. And prizewinner M realized that he had participated unawares in writing a chapter in one of the novels that the president habitually attributed to "its writer," without indicating its writer's true identity. 


\section{Bibliography}

Arabic surnames beginning with the article "al-" (also transliterated as "el-") are listed under the first letter after the article, e.g. El-Ariss is listed under A and not under E.

'Abd al-Amīr, 'Alī. "Rahāfat Muḥammad Khuḍayyir fì aqbiyat al-ra'īs." al-Masalla, Winter 2001.

http://www.aliabdulameer.com/inp/view.asp?ID=856

'Abd al-Amīr, 'Alī, “'Riwāyāt umm al-ma ārik' tuṭị̣ 'uzlat Muḥammad Khuḍayyir.” al-Hayāt, April 21, 2001.

http://www.aliabdulameer.com/inp/view.asp?ID=201

Aboul-Ela, Hossam. "Is there an Arab (yet) in this Field? Postcolonialism, Comparative Literature, and the Middle Eastern Horizon of Said's Discourse Analysis." MFS Modern Fiction Studies 56, no. 4 (2010): 729-50.

Albers, Yvonne, Georges Khalil, and Friedericke Pannewick. "Introduction: Tracks and Traces of Literary Commitment: On Iltizām as an Ongoing Intellectual Project." In Pannewick et al., Commitment and Beyond, 9-25.

El-Ariss, Tarek. Trials of Arab Modernity. New York: Fordham University Press, 2013. 
Al-Asadī, Muḥammad. "Wujūh al-ṣāni' al-amhar: qirā’'a fị Hadā 'iq al-wujūh." al-Nūrr, October 22, 2010.

http://www.alnoor.se/article.asp?id=94485

Berger, John. Success and Failure of Picasso. London: Granta Books, 1992.

Bhabha, Homi K. "DissemiNation: Time, Narrative, and the Margins of the Modern Nation." In Nation and Narration, ed. Homi Bhabha, 291-322. London and New York: Routledge, 1990.

Caiani, Fabio. Contemporary Arab Fiction: Innovation from Rama to Yalu. London and New York: Routledge, 2007.

Caiani, Fabio, and Catherine Cobham. "Autumn Visions: War and the Imagery of Muhammad Khuḍayyir.” Journal of Arabic Literature 49, no. 3 (2018): 243-70.

Caiani, Fabio, and Catherine Cobham. The Iraqi Novel: Key Writers, Key Texts. Edinburgh: Edinburgh University Press, 2013.

Casanova, Pascale. The World Republic of Letters. Trans. M. B. Debevoise. London and Cambridge, MA: Harvard University Press, 2004.

Ciofalo, John J. The Self-Portraits of Francisco Goya. Cambridge and New York: Cambridge University Press, 2001. 
Erickson, John. Islam and Postcolonial Narrative. Cambridge: Cambridge University Press, 1998.

Foucault, Michel. History of Madness. Trans. Jonathan Murphy and Jean Khalfa. London and New York: Routledge, 2006.

Guth, Stephan. "Between Commitment and Marginalization: The 'Generation of the Sixties' in the Sadat Era." In Pannewick et al., Commitment and Beyond, 125-42.

Al-Ḥalfī, 'Abd al-Jabbār. "Ghūyā [Goya] bayna Muḥammad Khuḍayyir wa-Būyrū Bāyīkhū [Buero Vallejo].” al-Nāqid al- 'Irāqū, June 28, 2009. http://www.alnaked-aliraqi.net/article/1749.php

Hall, Stuart. Familiar Stranger. London: Penguin, 2018.

Hassan, Waïl. "Postcolonialism and Modern Arabic Literature: Twenty-First Century Horizons.” Interventions 20, no. 2 (2018): 157-73.

Hassan, Waïl. "Postcolonial Theory and Modern Arabic Literature: Horizons of Application," Journal of Arabic Literature 33, no. 1 (2002): 45-64.

Al-Kharrāt, Idwār. al-Hassāsiyya al-jad̄̄da. Beirut: Dār al-ādāb, 1993. 
Khoury, Elias. "Between Solidarity and Pleasure: An Interview on World Literature with Elias Khoury." Interview by Anne-Marie McManus. Journal of World Literature 2, no. 3 (2017), 394-407.

Khoury, Elias. "Beyond Commitment." In Pannewick et al., Commitment and Beyond, 79-87.

Khuḍayyir, Muḥammad. "Frānkinshtāyn al- 'Irāqī.” al-Ṣabāh, October 30, 2013. http://www.alsabaah.iq/ArticleShow.aspx?ID=57207

Khuḍayyir, Muḥammad. Hadā'iq al-wujūh: aqni 'a wa-hikāyāt. Damascus: Dār almadā, 2008.

Khuḍayyir, Muḥammad. al-Hikēya al-jadìda. Amman: Dār azmina li-'l-nashr wa-'ltawZīì 1995.

Khuḍayyir, Muḥammad. "Ḥiwār ma 'a al-qāṣṣ Muḥammad Khuḍayyir.” Interview by Sa 'dūn Halīl. al-Hiwāar al-mutamaddin, February 9, 2014.

http://www.ahewar.org/debat/show.art.asp?aid=399815

Khuḍayyir, Muḥammad. Kurrāsat Kānūn. Amman: Dār azmina li-'l-nashr wa-'l-tawzī', 2004. First published 2001 by Dār al-shu'ūn al-thaqāfiyya, Baghdad.

Khuḍayyir, Muḥammad. Mā yumsak wa-mā lā yumsak: inshàa'àt sīriyya. Milan: Manshūrāt al-mutawassiț, 2017. 
Khuḍayyir, Muhammad. "al-Qișṣa al-qașīra hiya aqșar burhān 'alā 'aẓamat al-wujūd.” Interview by Hishām al-Bustānī. Hiber, August 26, 2018.

https://www.7iber.com/culture/interview-with-mohammad-khudayyir/

Khuḍayyir, Muḥammad. Rasā'il min thaqb al-sarațān. Beirut: Dār al-rafidayn, 2017.

Khuḍayyir, Muhammad. Ru'yā kharīf. Amman: Dār azmina li-'l-nashr wa-'l-tawzī', 1995.

Khuḍayyir, Muḥammad. al-Sard wa-'l-kitāb. Originally distributed with the magazine Dubay al-thaqāfiyya, May 2010. Available as a PDF file without numbered pages from the author's Facebook page:

https://www.facebook.com/mohammed.khudair?fref[ts

Milich, Stephan. "Narrating, Metaphorizing or Performing the Unforgettable? The Politics of Trauma in Contemporary Arabic Literature.” In Pannewick et al., Commitment and Beyond, 285-301.

Musawi, Muhsin. The Postcolonial Arabic Novel: Debating Ambivalence. Leiden: Brill, 2003.

Musawi, Muhsin, "Postcolonial Theory in the Arab World: Belated Engagements and Limits," Interventions 20, no. 2 (2018): 174-91. 
Musawi, Muhsin. Reading Iraq: Culture and Power in Conflict. London: I.B. Tauris, 2006.

Mustafa, Shakir. "Genre Negotiations: Review of Muhammad Khudayyir, Basriyatha:

Sūrat Madina. Baghdad: Manshūrat al-Amad, 1993." Edebiyat 13, no. 1 (2003): 105-9.

Naaman, Mara. "Disciplinary Divergences: Problematizing the Field of Arabic Literature.” Comparative Literature Studies 47, no. 4 (2010): 446-71.

Al-Nowaihi, Magda M. “The 'Middle East'? Or . . . /Arabic Literature and the Postcolonial Predicament.” In A Companion to Postcolonial Studies, eds. Henry Schwarz and Sangeeta Ray, 282-303. Malden (MA): Blackwell Publishing, 2000.

Omri, Mohamed-Salah. "Notes on the Traffic between Theory and Arabic Literature." International Journal of Middle Eastern Studies 43 (2011): 731-3.

Pannewick, Friederike, Georges Khalil, and Yvonne Albers, eds. Commitment and Beyond: Reflections on/of the Political in Arabic Literature since the 1940s. Wiesbaden: Reichert Verlag, 2015.

Rossetti, Joseph Henry. "A Shared Imaginary City: the Role of the Reader in the Fiction of Muḥammad Khuḍayyir.” PhD diss., University of Pennsylvania, 2017. Publicly Accessible Penn Dissertations. 2557. https://repository.upenn.edu/edissertations/2557 
Al-Sayyāb, Badr Shākir. al-A 'māl al-shi 'riyya al-kāmila, vol. 2. Beirut: Dār al-'awda, 2002.

Todorov, Tzvetan. Goya. Trans. Emanuele Lana. Milano: Garzanti, 2013. First

published in French as Goya. À l'ombre des lumières. Paris: Flammarion, 2011.

Zeidel, Ronen. "On Dictatorship, Literature and the Coming Revolution: Regime and Novels in Iraq 1995-2003." Nidaba 1, no. 2 (2017): 62-74.

\footnotetext{
1 'Abd al-Amīr, "Riwāyāt umm al-ma ārik."

${ }^{2}$ For more details about Khudayyir in relation to other Iraqi writers and his response to war; see Caiani and Cobham, "Autumn Visions," 244-47.

${ }^{3}$ Bașrayāthā (1993; translated into English by William M. Hutchins as Basrayatha: The Story of a City,
} 2008) is Khudayyir's first collection of short texts that include essays, fiction and combinations of the two. The difference between Kurrāsat and Bașrayāthā is that most of the texts of the latter had been published individually in Iraqi newspapers and periodicals in the 1990s, whereas we have no evidence that any section of the former had appeared prior to the book's publication. For a detailed discussion of Bașrayāthā, see Rossetti, “A Shared Imaginary City,” 270-87.

${ }^{4}$ Khuḍayyir, "Hiiwār ma'a al-qāṣṣ."

${ }^{5}$ Hassan, "Postcolonialism and Modern Arabic Literature," see especially 163-7.

${ }^{6}$ Omri, "Notes on the Traffic," 732.

${ }^{7}$ See Caiani, Contemporary Arab Fiction, 121-2 and more recently Albers, Khalil, and Pannewick, "Introduction", 13-14; Guth, "Between Commitment and Marginalization," 126-7, and Khoury, "Beyond Commitment," 84.

${ }^{8}$ Kharrāt, al-Hassāsiyya al-jadīda, 15-20.

${ }^{9}$ See Erickson, Islam and Postcolonial Narrative, 25-6, for a discussion of the métissage of genres in the Maghrebi francophone novel.

${ }^{10}$ In Iraq under the rule of the Ba 'th party, writers like Fu' ād al-Takarlī and Mahdī 'Īsā al-Ṣaqr wrote novels which, while clearly focusing on Iraqi society by discussing paradigmatic social characters (without dealing with politics directly), could be read symbolically as being critical of a certain form of ruthless power. Predictably, some Iraqi writers chose silence or exile as a form of political noncompliance, and some others were punished by the regime for their defiant stance (Musawi, Reading Iraq, 76; Zeidel, “On Dictatorship;” Rossetti, “A Shared Imaginary City,” 95-109). Thanks to his Moscow exile, the novelist Ghā'ib Țu'ma Farmān could write a novel like al-Markab (1989; "The Boat"), in which he criticised the emergence of a sort of mafia state in Saddam's Iraq. All the novelists mentioned here have written sophisticated and compelling novels which, however, we can 
summarily categorise as belonging to the genre of mimetic realism (for a discussion of the works of these novelists, see Caiani and Cobham, The Iraqi Novel). As we have mentioned already, Khuḍayyir's Kurrāsat is a composite text which, even if presented by the publisher as riwāya, "a novel," is a hybrid text, rather than a conventional novel.

${ }^{11}$ Khuḍayyir, "Ḥiwār ma 'a al-qāșṣ." See also Khuḍayyir, al-Hikāya al-jadīda, f. 32, p. 32, 63.

${ }^{12}$ Hassan, "Postcolonialism and Modern Arabic Literature," 169, 168.

${ }^{13}$ For a comprehensive discussion of Kurrāsat that also highlights its significant references to preIslamic, Sumerian Iraq, see Rossetti, “A Shared Imaginary City,” 211-21.

${ }^{14}$ Similarly to Kurrāsat and unlike his first short story collection al-Mamlaka al-sawdā' ("The Black Kingdom”, 1972), both his second and third collections Fī darajat khamsa wa-arba 'in mi' awī ("At 45 Degrees Centigrade,” 1978) and Ru'yā kharīf (“An Autumn Vision”, 1995) have brief introductions full of indirect comments and allusions to the stories included in the collections. These comments and allusions are often open to interpretation. The same applies to Hadā'iq al-wujüh.

${ }^{15}$ Khuḍayyir, Kurrāsat Kānūn, 9. Further citations to this work are given in the text. It is worth noting here that the ambiguity of modern Iraqi identity, especially in the recent period of sectarian violence where different groups do not understand one another and there is little transparency even within the groups, has inspired writers to create fictional "monsters." In his novel Frānkinshtāyn fì Baghdād (2013; Frankenstein in Baghdad, 2018) Aḥmad Sa dāwī creates a Baghdadi Frankenstein who is fluidly conceived of as monster, superman and everyman.

${ }^{16}$ For a reference to figurative art as a major influence in his first three short story collections, see Khuḍayyir, al-Sard wa-'l-kitāb, 93. The short story "al-Șurkha" (1972) is inspired by "The Snake Charmer," a painting by Henri Rousseau, "Echo of a Scream" by the Mexican painter David Siqueiros, and Giacometti's statues (ibid.), but in the text of the short story only the first source of inspiration is acknowledged. On the cover of the 2004 second edition of Kurrāsat, by the Jordanian publisher Azmina, we find reproduced Goya's etching n. 43 El sueño de la razón produce monstruos, Henry Moore's drawing Group of Draped Figures in a Shelter (1941) and Picasso's painting Guernica (1937). These non-realistic examples of figurative art resonate with Khuḍayyir's narrative work, which relies on a non-mimetic representation of a certain traumatic event (we do not know whether the writer had any say in the selection of these specific works to be reproduced on the cover of his book).

${ }^{17}$ Berger, Success and Failure of Picasso, 59.

${ }^{18}$ For an analysis of another notable fictional narrative that is a feature of the last chapters of Kurrāsat, see Rossetti, “A Shared Imaginary City,” 219-21. Khuḍayyir’s numerous references to, and observations on, the life and work of Goya, Picasso and Moore are an implicit invitation to his readers to discover or rediscover the work of these artists.

${ }^{19}$ Khudayyir is fond of quoting and paraphrasing the title of Capricho n. 52: Lo que puede un sastre! ("Is there anything a tailor can't do!"). He quotes this title throughout Kurrāsat and also in some of his other texts (see for example, Khuḍayyir, Mā yumsak, 16).

${ }^{20}$ al-Ḥalfí, "Ghūyā [Goya] bayna Muhammad Khuḍayyir,” 2009.

21 "Abd al-Amīr, "Riwāyāt umm al-ma ārik." 
${ }^{22}$ For another criticism of the regime implicit in a section of Kurrāsat, see Rossetti 2017: 217.

${ }^{23}$ Khuḍayyir, Ru' yā kharîf, 17-24.

${ }^{24}$ Caiani and Cobham, "Autumn Visions,” 263.

${ }^{25}$ Foucault, History of Madness, 531; Todorov, Goya, 80-91.

${ }^{26}$ Ciofalo, The Self-Portraits, 68.

${ }^{27}$ The titles "The Duchess of Alba" and "A Sail beyond the Tigris" seem quite straightforward in their allusions (the former refers to Goya's lover and patron, the latter is a reference to Ahmad Shawqī's poem turned into a song by Muhammad 'Abd al-Wahhāb's "Yā shi āran warā’ Dijla"). The other titles offer unexpected pairings that mix references to the military world (the bomber, the platinum armor of Schwarzkopf, the American general who planned and led Operation Desert Storm in 1991, the B52) with the world of American popular culture (Madonna) and Arab-Islamic culture (Qut alQulub, and Qays; the latter, who falls in love with Layla in Arabic and Persian literature, is here paired with a certain Monica, possibly a mischievous allusion to Monica Levinsky with whom president Bill Clinton had a sexual relationship in the mid-1990s).

${ }^{28}$ Todorov, Goya, 80.

${ }^{29}$ Todorov, Goya, 113.

${ }^{30}$ Khuḍayyir, Ru'yā kharīf, 10.

${ }^{31}$ See Khuḍayyir, Mā yumsak, 16, for Khuḍayyir's own comments on the significance of Kurrāsat within its political context.

${ }^{32}$ See Rossetti, "A Shared Imaginary City," 221-9 for a perceptive discussion of Hadā' $i q$ that refers to Iser's reader response theory. The Iraqi poet Muhammad al-Asadī hails Hadā' $i q$ as a watershed text "in the history of Iraqi and Arabic literature," thanks to the ambitious way in which Khuḍayyir draws on a variety of texts and genres (al-Asadīi, "Wujūh al-șāni' al-amhar." See esp. part 2). AlAsadī also emphasizes the dominance of poets as the sources of inspiration for Khuḍayyir, "one of the most prominent short story writers and innovators in both theory and practice" (Ibid., footnote 1).

${ }^{33}$ Musawi, "Postcolonial Theory," 186.

${ }^{34}$ Hall, Familiar Stranger, 16.

${ }^{35}$ Khudayyir confirmed in an interview that in $\operatorname{Had} \bar{a}^{\prime} i q$ he tried to mix fiction and autobiographical writing (Khuḍayyir, "Hịwār ma a al-qāṣṣ").

${ }^{36}$ This is significant also because his turning sixty more or less coincides with the turn of the millennium and the book includes references to a sort of millenarianism. Moreover, as Khuḍayyir reminds his readers in Hadā 'iq, Abū al-'Alā' al-Ma' arrī (973-1057) was sixty when he received a letter from the grammarian Ibn al-Qārih to which he replied with his Risālat al-ghufrān (The Epistle of

Forgiveness; Khuḍayyir, Hadā'iq al-wujūh, 190. Further citations to this work are given in the text). We will see below how Khuḍayyir's interaction with al-Ma arrī alludes to one of the meanings of this work.

${ }^{37}$ Mustafa writes about Khudayyir's fiction from the 1980s and 1990s: "As a response to the Iran-Iraq war, [Khudayyir's] fiction has completely done away with the idea of the hero." (Mustafa, "Genre Negotiations," 109). 
${ }^{38}$ See for example the short stories "Sā'ât ka-khuyūl" (translated into English as "Clocks like Horses" by Denys Johnson-Davies; 1980) and "al-Ḥājj” ("The Pilgrim") in his collection Fī darajat khamsa waarba 'īn mi'awì (1978). "Ihtidịār rassām" ("The Death of a Painter"), in the same collection, is set in Baghdad but focuses on the rich cosmopolitan nature of Ottoman Iraq. Khuḍayyir often refers to Basra as a melting pot: "Basra that al-Jăhị described as 'the dock of India' [hawd al-Hind], on whose banks all kinds of migrants mingle and their languages collide, and where the germs of the world enter and ships from East and West bring all kinds of new inventions in the vanguard of every raid and occupation" (Khuḍayyir, Mã yumsak, 11).

${ }^{39}$ In the first chapter of Kurrāsat, Khuḍayyir writes approvingly of paintings by Goya and Picasso depicting people on the fringes of society where, despite the melancholy subject matter, the details make us "participants in that moment of empathy" between the painters and their subjects (Khuḍayyir, Kurrāsat Kānūn, 18-19).

${ }^{40}$ Khuḍayyir, Mā yumsak, 39.

${ }^{41}$ See Musawi, "Postcolonial Theory," 181 for examples of earlier attempts to appropriate and exploit the colonial archive by Iraqi writers.

${ }^{42}$ Khuḍayyir, Mā yumsak, 11.

${ }^{43}$ This and the preceding two quotations are all from Khuḍayyir, Mã yumsak, 13.

${ }^{44}$ Fanon quoted in Bhabha, "DissemiNation," 303.

${ }^{45}$ Bhabha, "DissemiNation," 303.

${ }^{46}$ See esp. Hassan, "Postcolonialism and Modern Arabic Literature," 167, but also Hassan, "Postcolonial Theory," Aboul-Ela, "Is there an Arab (yet) in this Field?," Naaman, "Disciplinary Divergences," alNowaihi, "The 'Middle East'?" Within the context of Arabic texts engaging directly with the colonial legacy, Al-Musawi refers to the seminal and, until recently largely overlooked, novel $\mathrm{Dr}$ Ibrāhīm ("Dr Ibrahim", 1939) by the Iraqi pioneer novelist Dhū al-Nūn Ayyūb (Musawi, "Postcolonial Theory," 184-5. For discussions of the novel see Musawi, The Postcolonial Arabic Novel, 64-7, 340-1; Caiani and Cobham, The Iraqi Novel, 10). According to Hassan, Ṭayyib Șāliḥ's novel Mawsim al-hijra ilā al-shamāl (1966; Season of Migration to the North, 1970) partly acquired its "status as the most canonical Arabic novel in postcolonial studies [because] it 'writes back' to Conrad's [Heart of Darkness], one of the most canonical narratives of empire" (Hassan, "Postcolonialism and Modern Arabic Literature," 167).

${ }^{47}$ The title of the book ("The Gardens of the Faces") is taken from a line from Sayyāb's poem "Amām bāb Allāh" (1961; "Before the Gate of God", 1970, see al-Sayyāb, al-A 'māl al-shi 'riyya, 222).

${ }^{48}$ The presence of Iranian poets in this list is also noteworthy as Khuḍayyir lived in Basra which was at the center of a violently contested region during the eight long years of the war between Iraq and Iran (1980-1988). For a possible anti-war aside in a story written at the apex of the military clashes in the South of Iraq, see Caiani and Cobham, "Autumn Visions," 266, footnote 72.

${ }^{49}$ Hassan, "Postcolonialism and Modern Arabic Literature," 168. Thus Khuḍayyir can be seen to revive the legacy of Iraq's first modern novelist, Mạ̣mūd Aḥmad al-Sayyid, who in his seminal novel Jaläl Khälid (1928) points at a potentially fruitful intellectual-political connection between Iraq and India through an anti-colonial socialist prism (Musawi, "Postcolonial Theory," 181; Caiani and Cobham, The 
Iraqi Novel, 10). In Hadā iq, Khuḍayyir develops further the connection between Iraq and India when he evokes the meeting between Tagore and the great Iraqi poet Jamīl Șidqī al-Zahāwī in 1932. Typically, Khudayyir finds inspiration in a photograph that depicts the Iraqi poet slumped on a chair, having fallen asleep while awaiting Tagore in the train station of the Iraqi town of Khānaqīn, on the border with Iran. Of the two poets, he also writes: "both grew up in the mire of despotic foreign rule" (Khudayyir, Hadā'iq al-wujūh, 67).

${ }^{50}$ Casanova, The World Republic, xiii. Further citations to this work are given in the text.

${ }^{51}$ See Khoury's "Between Solidarity and Pleasure," 395, 396 for his thoughts on the connections between Arabic literature and non-Western literatures.

${ }^{52}$ Khuḍayyir, Mā yumsak, 16. Even though these European artists are far from articulating a colonial, Eurocentric discourse, it is significant that Khudayyir should rely on works that are seen as canonical examples of European "high art" to express a universal condemnation of war and violence.

${ }^{53}$ Khuḍayyir, Rasā'il min thaqb, 224.

${ }^{54}$ Khuḍayyir, Rasā' $i l$ min thaqb, 226.

${ }^{55}$ Khudayyir, Mā yumsak, 17.

${ }^{56}$ See the chapter "Hacking the Modern" in El-Ariss, Trials of Arab Modernity, 145-71.

${ }^{57}$ Milich, "Narrating, Metaphorizing," 295.

${ }^{58}$ In his review of Aḥmad Sa dāwī’s Frānkinshtāyn fì Baghdād, Khuḍayyir obliquely criticizes both Sa dāwī’s novel and Jamāl Ḥusayn 'Alī’s Amwāt Baghdād ("The Dead of Baghdad”, 2008), seemingly for their inability to go beyond reflecting the horror of the Iraqi reality (Khudayyir, "Frānkinshtāyn al-'Irāqī”).

${ }^{59}$ Khuḍayyir, al-Hikāya al-jadīda, 20.

${ }^{60}$ We should remember that as long ago as the late 1990s Edward Said distanced himself from postcolonial studies for their insufficient attention to neocolonialism (Hassan, "Postcolonialism and Modern Arabic Literature," 158).

${ }^{61}$ This and the preceding quotation are both from 'Abd al-Amīr, "Rahāfat Muhammad Khuḍayyir." 
Muhammad Khuḍayyir from Saddam Hussein to the Gardens of the South: Writing the Self in Postcolonial Basra.

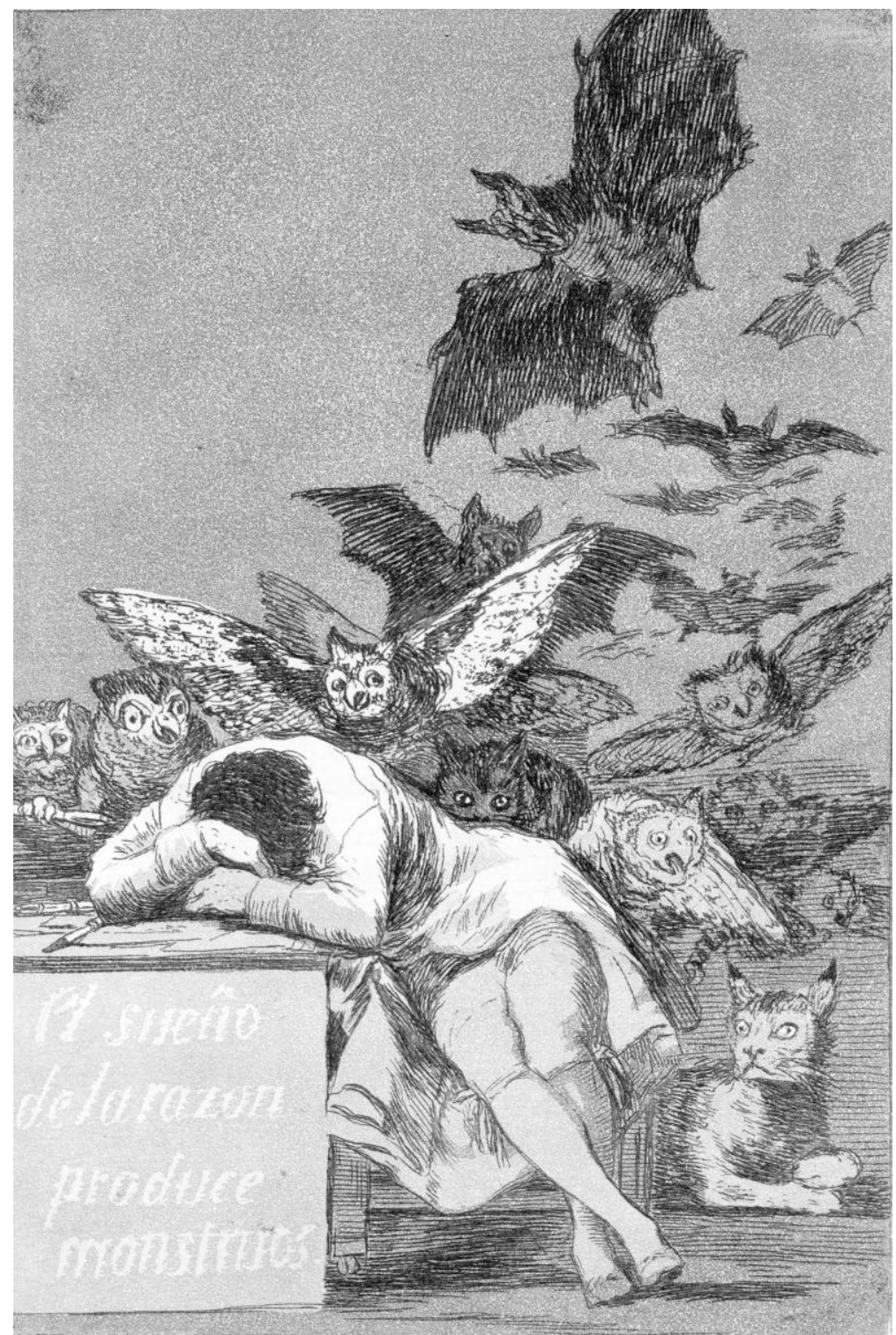

Figure 1

Goya (Francisco de Goya y Lucientes), “The Sleep of Reason Produces Monsters” (“E1 sueño de la razon produce monstruos"), Plate 43, Los Caprichos, 1799. Print. The Metropolitan Museum of Art, New York. Gift of M. Knoedler \& Co., 1918. www.metmuseum.org 


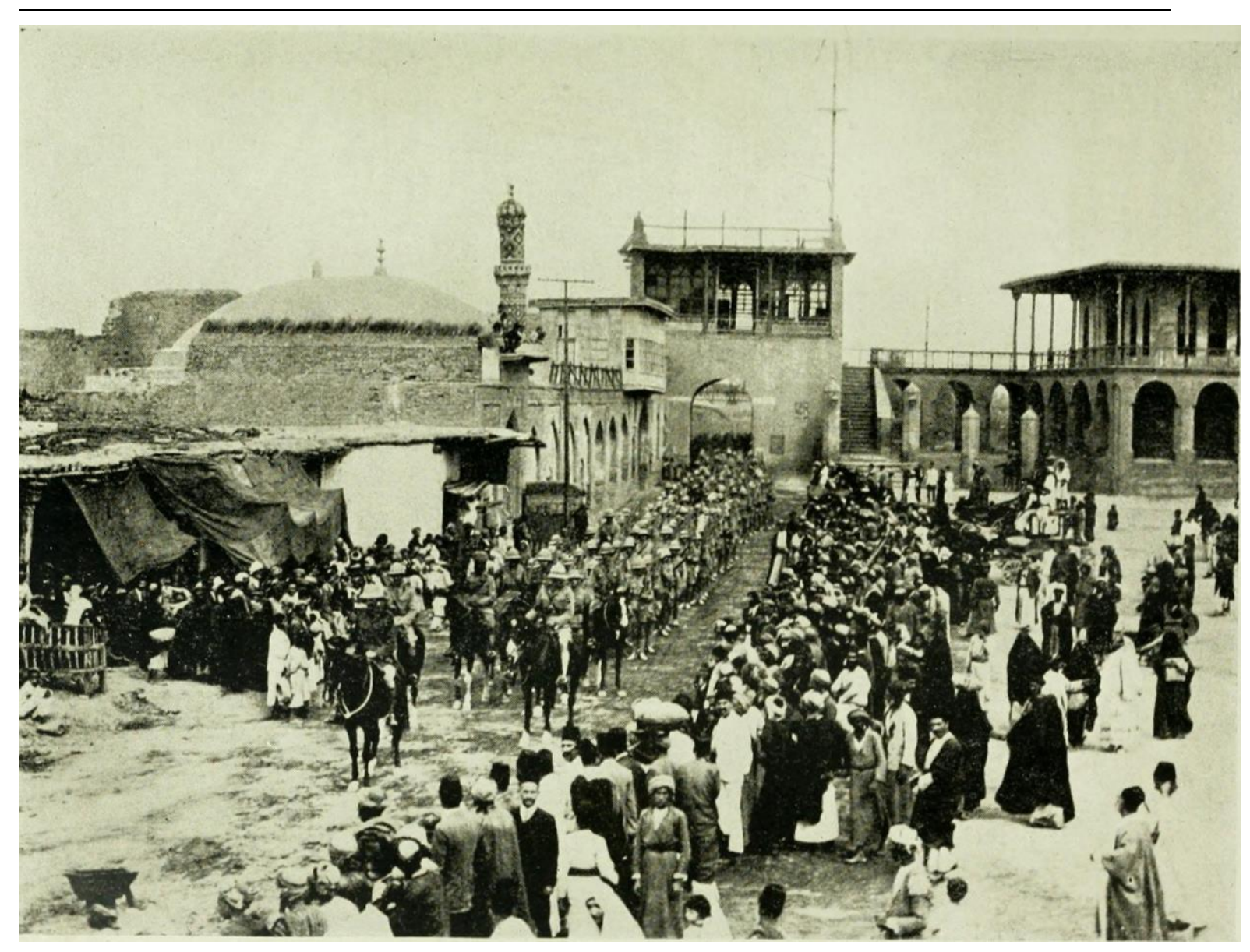

Figure 2

“Sir Frederick Stanley Maude leads the Indian Army into Baghdad. 1917.” Mrs. Stuart

Menzies (1920). Sir Stanley Maude and Other Memories. London: Herbert Jenkins. p.

48. 